\title{
REGISTER ANALYSIS OF DUBBING AND SUBTITLING OF “LIFE OF PI"
}

\section{Najmeh Bahrami Nazarabadi Ghazalossadat Fatemi}

\begin{abstract}
The controversial issue in the translation field is the assessment of the quality of the translations. Therefore, the present study set out to examine the register of the film "Life of Pi" and then to find out the mismatches in registers of dubbing and subtitling some excerpts of this film in Persian. This process was done based on the House's model of TQA (translation quality assessment). The theme of dubbing and subtitling were compared and contrasted in both English, the original language of the film, and Persian based on the register analysis in order to decipher the most frequent translation method and of course the mismatches. The most important mismatches occurred in the field of registers were discussed in the body of the study in detail and the rest of the analysis were brought in a table in appendices. Finally, the intended meaning was fulfilled as House's expectation of a proper translation.
\end{abstract}

Keywords: House's model of TQA, Dubbing, Subtitling, Register analysis, Life of Pie

\section{Introduction}

Technology, mobility and communication have been widespread nowadays. An advanced technology enables viewerto watch variousforeigntelevision programs. Therefore, translation as an area of interlingual communication plays a significant role. 
Audiovisual translation (AVT) is a sub-field of translation studies and is defined as translation of product in which the verbal dimension is supplemented by principle in other media. Generally speaking, "audiovisual language transfer denotes the process by which a film or television program is made comprehensible to a target audience that is unfamiliar with the original's source language" (Luyken, 1991:11). Dubbing and subtitling are the most common type of AVT. Dubbing is oral and the voices of actors on the sound track are replaced by another language. Because of larger cost of dubbing, subtitling has emerged a way to deal with another language. Subtitling is defined as translating of verbal information in media in a specific language in one or three lines of written text which are presented on the television screen (Gottlieb, 2004). Subtitling is a new field in Iran. There is the lack of educated professional subtitles at work. Therefore, many films are subtitled by special softwares without human interference and cause awkward and inappropriate translation for the viewers. Thus, assessing these kinds of translation is necessary and should be noticed considerately.

The assessment of translation of the dialogues of the films in dubbing and subtitling is done by following different models; one of the models is House's model which is selected to be applied in this research. House (2001) stated "translation is viewed as the recontextualization of a text in L1 by a semantically and pragmatically equivalent text in L2" (P.247). She differentiated 2 kinds of translations as cited in Munday (2012) covert translation is "A translation which enjoys the status of an original source text in the target culture" and overt translation is "One in which the addressees of the translation text are quite "overtly" not being directly addressed"(P.142). Function and meaning are regarded as the most important elements that should be equivalent in translation; therefore, the functional pragmatic equivalent is the most appropriate kind of equivalence in this model which requires function or the context of situation. According to House (2001), register is the context of situation which consists of three components: field, tenor and mode (Figure. 1 in Appendices).

Field: What the text is about, what kinds of things are in the text. 
Tenor: How the author, the reader, and the person in the text, relate to each other through the text.

Mode: How the text is communicated; how its parts fit together as a text.

Analyzing these three segments which is called register analysis is going to be performed on dubbing and interlingual subtitling of a movie in this study.

This model was chosen for this study as to the best of the researchers' knowledge; there is a gap in applying this method on the translations done from English into Persian especially in the area of film industry, i.e. in subtitling and dubbing, in Iran. This special film was considered as it is full of dialogues between different characters with different registers; therefore, the researchers prefer to apply this method to identify the registers and also to understand whether the translators had recognized these differences or not.

The objective of this study is to evaluate the translations done in subtitled and dubbed versions of "Life of Pie" by applying House's register analysis, then the researchers tried to find out differences and similarities between these two translations. Finally it will be possible to mention the most frequent method used by the translators.

\section{Literature Review}

As mentioned above, House's model was mostly applied on the corpus based studies, i.e. on written texts, in Iran; therefore in the following you can consider samples of these studies.

Khedmatgozar and EslamiRasekh (2013), focused on the issues of translation quality assessment. They attempt to identify the comparative quality of two Persian translations of the English novel Ben in the World (by Dorris Lessing) at a register level. The researchers found out that shortcomings are attributed to the difficulties across the two languages. The compared translations demonstrated the ways the translation efficiency could be detected by the model of assessment. 
Shakernia (2014) tends to apply House's model on a novel named the Grapes of Wrath by John Stein Beck. It is translated by Mohammad Sadegh Shariati. She applies House's model on this book through the analysis of the translation and the source text to find out whether the translations are covert or overt.

Bahrami and Ameri (2014), desired to discuss register analysis in dubbings from English into Persian .The corpus studied is one of the American movie and its Dubbing into Persian, by applying House's TQA (register analysis). The findings revealed that the model considered several mismatches and it seems that it was not applicable precisely because it considered some deviations as mismatches while these deviations inevitably happen in dubbings, and cannot be labeled errors. The researchers finally discussed that the dubbings can be appropriate and acceptable according to socio-cultural norms of the Iranian context and house's model is not the perfect model of analyzing the dialogues of the films.

One of the inspiring articles to do this research was written abroad and was a study done by Pettit (2014). This study discussed the verbal and non-verbal components of the audio-visual texts and discussed the interaction between image and the verbal. He mentioned that subtitling and dubbing are different genres which should be differentiated by the translators to perform better. The other one was the local article written by Bahrami and Ameri (2014) wherein they considered House's model on one of the American movie.

The above articles were guidelines to do this research and in order to understand the differences between the genres of subtitling and dubbing, House's model was applied.

\subsection{House's model of translation quality assessment}

\subsubsection{House's definition of translation}

According to House (1981), "translation is the replacement of a text in the source language by a semantically and pragmatically equivalent text in the target language"(P.30). 


\subsubsection{House's model fundamentals and definitions}

House's model of translation quality assessment provides the analysis and comparison of an original and its translation. House (2001) gave the meaning of equivalence as the fundamental criterion of translation quality. As it is clarified by House (2001), equivalence cannot only be related to syntactic, formal and lexical similarities; therefore, languages separate reality in different ways. So House (2001) expressed that the functional pragmatic equivalence is the most appropriate kind and she combined the preservation of meaning across two different cultures and languages. The preservation of meaning and function is the main focus of House in defining translation.

According to House (2001), function or context of situation should not be separated from text in the process of translation quality assessment and context of situation which is called register. House introduced register analysis for translation quality assessment which has three particular features: field, mode, and tenor (2001) "Field captures social activity , subject matter or topic , including differentiations of degrees of generality, specificity or "granularity" in lexical items according to rubrics of specialized, general and popular, "Tenor refers to the nature of the participants , the addresser and the addressees, and the relationship between them in terms of social power and social distance, as well as degree of emotional charge ,"Mode refers to both the channel_spoken or written_and the degree to which potential or real participation is allowed for between writer and reader "(P.248).

\subsubsection{House's types of translation}

She has also distinguished 2 types of translation: overt and covert. According to House (2001):

In overt translation, the work of the translator is important and visible. Since it is the translator's task to give target culture members access to the original text and its culture impact on source culture members, the translator puts target culture members in a position to observe and/or judge this text "from outside. (P.250)

She mentioned that Covert translation psycho-linguistically is less

\section{Translation Today}


complex and more deceptive than overt translation at the one time.

House has claimed in Munday (2012), that in fact subtitling is an obvious instance of overt translation, because it makes the TT reader remembered visually of the translated words throughout the film and dubbing is an instance of covert translation as the viewers don't have access to the dialogues of the film in the original language and can manipulate them according to his own ideology.

\subsection{Dubbing vs. Subtitling}

Dubbing is the most expensive method of audiovisual translation; While, subtitling is much cheaper and withholds the original dialogue that gives the viewer opportunities to hear the original actors' voices. Subtitling is really limited by space; therefore, reduce more the original information than dubbing. Dubbing might also reduce a viewer's ability to acquire a new language. Subtitling opens up minds to pick and preference ways of thought, cultures besides new languages. In some cases, dubbing is preferred for children and those who are restricted with degree of literacy than subtitling.

\subsection{Research Questions}

For applying House's model to the subtitled and dubbed versions of the film and for better handling of the data analysis, the researchers followed two research questions:

1. What are the differences and similarities between the registers in dubbed and subtitled versions of "Life of Pie" based on House's model of register analysis?

2. Which one of the methods of translation introduced by House is more frequent in this film, i.e. covert or overt translation?

As mentioned above, finding out whether the translators were able to understand different registers of this film was so interesting for the researchers. So the aforesaid research 
questions helped them a lot in gaining this goal.

\section{Methodology}

This study focused on an English movie "LIFE OF PIE" with its Persian subtitling \& dubbing version. This film was nominated for three Golden Globe Awards for the Best Picture Drama and the Best Director and won the Golden Globe Award for Best Original Score. At the 85th Academy Awards it had eleven nominations, including Best Picture, and won four (the most for the evening) including Best Director for Ang Lee.

After watching different films and analyzing them from register analysis point of view, the above film was selected as it was nominated for different awards and also suited in this study well. The researchers have passed the following stages to collect and analyze the data. First, the revised functional-pragmatic model of translation evaluation of House (1997) has been selected as the model of the research because, as mentioned before, in this field a gap felt by the researchers. Second, the film “Life of $\mathrm{Pi}^{\prime \prime}$ has been selected as the material. Third, 5 random coordinated segments of script, dubbing, and subtitling of the film have been selected and analyzed concerning their register: field, tenor and mode and these scripts occurred between different characters of the film. Fourth, the mismatches of the analyzed registers have been marked and shown in tables in the following discussion. Finally, the more frequent translation method was mentioned which will be helpful to the translators as they can identify which method is the best for translating different registers and also they recognized that they shouldn't stick to one method of translation and where possible they can shift between both of the methods.

\section{Results and Discussion}

"Life of $\mathrm{Pi}^{\prime}$ is an adventure drama film directed by Ang Lee based on Yann Martel's novel. It urges a tolerance of people and set of belief and principle that influence the way people live. The basic story in this film revolves around an Indian man named " $\mathrm{Pi}$ ", now living in Canada and telling a novelist about his life story and how at 16 he survives a shipwreck in which all passengers die.

\section{Script 1}

\section{Translation Today}


Novelist:You were raised in a zoo?

Pi:Born and raised in Pondicherry, in what was the French part of India. My father owned the zoo, and I was delivered on short notice by a Herpetologist who was there to check on the Bengal Monitor Lizard. Mother and I were both healthy but the poor lizard escaped.

\section{Field:}

This excerpt reveals a conversation between two friends. The segment illustrates a colloquial language that has a characteristic accent, Indian and Canadian.

In this excerpt, cases of friendship can be seen by features of auditory and visual.

\section{Tenor:}

\section{Characters' Temporal, Geographical and Social Provenance:}

The novelist has Canadian accent, has published two books, and was inspired to write Pi's life story during a trip to India.

While the man whose name was Pi has an Indian accent, both contemporary and middle-class.

\section{Characters' personal stance:}

$\mathrm{Pi}$ is deeply intrigued by the habits and characteristics of animals and people. He is sweet-tempered, tolerant, assertive and an inquisitive man.

The novelist is a positive, bright and outgoing man.

\section{Social role relationship:}

The two characters are strangers that Mamaji, Pi's teacher, introduced Pi to the novelist, friend of Mamaji, for his wonderful story.

\section{Social role attitude:}

The conversational style mixed with slang is seen between the two characters. 


\section{Mode:}

This segment is fully spoken as well as conversational and simple. The participation is simple too.

\section{Dubbing1}

$$
\text { رمان نويس: يس تو تو باغ وحش بزرگ شدى؟ }
$$

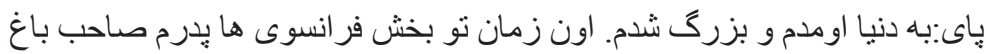

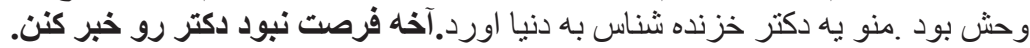

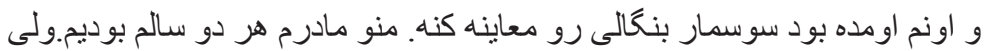
سوسمار بدبخت فرار كرد.

\section{Subtitling 1}

$$
\begin{aligned}
& \text { رمان نويس:بِ تو در يه باغ وحش بزرگ شدى؟ }
\end{aligned}
$$

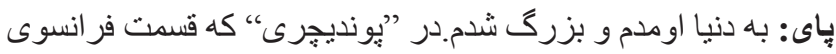

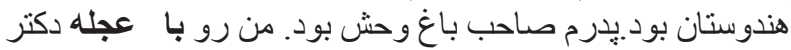

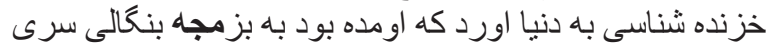

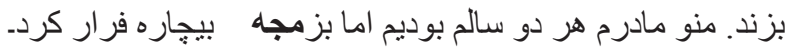

\section{Field:}

The dubbed excerpt lacks characteristics accent like Indian and Canadian. Although the dubbed and subtitled excerpts follow the main plot of the original movie the censorship can be seen in some few parts. The Subtitled excerpt is more specific than the dubbed version.

\section{Tenor:}

\section{Characters' Temporal, Geographical and Social Provenance:}

In dubbed version the accent of characters has not been transferred. But, the characters contemporary, middle class languages can be seen in both dubbed and subtitled excerpts. Therefore, the only mismatch is the accent which is difficult to be kept in the TL. 


\section{Characters' personal stance:}

In dubbing it is tried to keep the characteristics of Pi that is deeply intrigued by the habits and characteristics of animals. He is sweettempered, tolerant, assertive and an inquisitive man.

The novelist is a positive, bright and outgoing man. Thus there is no mismatch in this part.

\section{Social role relationship:}

This part is the same as the original and no differences can be understood.

\section{Social role attitude:}

The same as the original, the conversational style is mixed with slang.

\section{Mode:}

The dubbed version is fully spoken as well as conversational and simple. The participation is simple too. The frequent use of broken words is seen and the type of translation is Covert.

The subtitling version is fully written and as it can be seen the type of translation is Overt.

\section{Script2}

Pi: What elsedo you want from me?

\section{Japanese shippingCompany:}

A story that won't make us look

Likefools.We need a simpler story for ourreport. One our company can

understand. A story we can all believe. 


\section{Field:}

This excerpt reveals a conversation between two strangers, $\mathrm{Pi}$ and the members of a Japanese company. The segment illustrates an informal language that has a characteristic accent of Indian and Japanese.

In this excerpt, the sense of understanding and caring about Pi's story cannot be seen.

\section{Tenor:}

\section{Characters' Temporal, Geographical and Social Provenance:}

The members of Japanese company have Japanese-Canadian accent, and were eager to write Pi's story during a trip by Japanese ship and what happened thereafter.

While "Pi" has an Indian accent which is both contemporary and middle-class.

\section{Characters' personal stance:}

$\mathrm{Pi}$ is deeply interested in characteristics of animals. He is a tolerant, bright, assertive and articulate man.

Members of Japanese company are strict, bad-tempered, impatient and rarely friendly.

\section{Social role relationship:}

The characters are strangers that the members of Japanese company came to him for their report about his story.

\section{Social role attitude:}

The conversational style is mixed with informal language can be seen between the characters.

\section{Mode:}

This segment is fully spoken as well as conversational.

\section{Dubbing2}

\section{Translation Today}




$$
\text { پإى: ديخه از من جى مى خو اين؟ }
$$

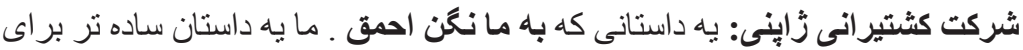

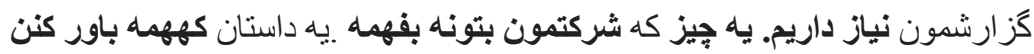

\section{Subtitling2}

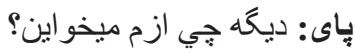

$$
\begin{aligned}
& \text { شركت كثتير انى زُإينى: يه داستاني كه ما رو احمق نشون نده } \\
& \text { ما يه داستان سادهتر بر اي كز ارشمون ميخوايم } \\
& \text { داستاني كه شركت ما بفهمه. داستاني كه همه ما باور كنيم }
\end{aligned}
$$

\section{Field:}

The subtitled and dubbed excerpts present a conversation between $\mathrm{Pi}$ and a member of company. The dubbed version has also attempted to keep the characteristics accent like Indian and Japanese the same as the original script.

\section{Tenor:}

\section{Characters' Temporal, Geographical and Social Provenance:}

In dubbed version the accent of characters has been transferred. The characters' contemporary, middle class languages can also be seen.

\section{Characters' personal stance:}

In dubbing and subtitling, the translator also tried to keep the characteristics of $\mathrm{Pi}$ that is deeply interested in characteristics of animals. He is a tolerant, bright, assertive and articulate man.

The character of Members of Japanese company are preserved in subtitling and dubbing.

\section{Social role relationship:}

In this part there is no mismatch between the original and subtitling and dubbing versions. 


\section{Social role attitude:}

The same as the original, the conversational style is mixed with informal language.

\section{Mode:}

The dubbed version is fully spoken as well as conversational. The frequent use of broken words is seen and the type of translation is Covert; While, the subtitled copy is fully written and the type of translation is Overt.

\section{Script3}

Pi: Why would a god do that? Why would he send his own son to suffer

For the sins of ordinary people?

Priest: Because He loves us. God made Himself approachable to us - human -

so we could understand Him.

\section{Field:}

This excerpt reveals a conversation between $\mathrm{Pi}$ and the priest. The segment demonstrates a colloquial language that has a characteristic accent Indian.

The matter in hand is about God, His prophet and His servants.

\section{Tenor:}

\section{Characters' Temporal, Geographical and Social Provenance:}

The priest and Pi both have an Indian accent. They met each other in church. Pi is interested in God, His prophet, His servants and all His creatures. The priest gladly given Pi something he desires to know more about them.

\section{Characters' personal stance:}

$\mathrm{Pi}$ is keenly interested in God and His creatures. He is bright, articulate and curious man.

The priest is sweet-tempered, patient and friendly. 


\section{Social role relationship:}

The characters are strangers. They accidentally meet each other in church.

\section{Social role attitude:}

The conversational style mixed with comradely chat is seen between the characters.

\section{Mode:}

This segment is fully spoken as well as friendly conversation.

\section{Dubbing3}

$$
\begin{aligned}
& \text { پإى : جرا بايد يكى رو بفرسته كه بخاطر كناه ادماى عادى عذاب بكثه؟ } \\
& \text { كثيش: جون مارودوست داره. خدا خودش رو در معرض ما انسان ها قرار داده تا } \\
& \text { بتونيم دركش كنيم }
\end{aligned}
$$

\section{Subtitling3}

$$
\begin{aligned}
& \text { بإى:جر ا يه خدا بايد جنين كاري كنه؟ } \\
& \text { جر ا اون بايد بِر خودش را بفرسته تا } \\
& \text { بخاطر كناهان مردمان عادي، زجر بكثه؟ } \\
& \text { كشيش: جون اون عاشقمونهذا خودش رو به ما انسانها نزديك كرده تا بتونيم اون }
\end{aligned}
$$

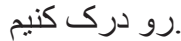

\section{Field:}

The excerpt manifests a conversation between the priest and $\mathrm{Pi}$. The dubbed has also attempts to keep the characteristics accent, Indian, and their friendly relations.

The translator did not get the meaning; instead of saying the prophet as 'son of god' he rendered 'the one' in a dubbing script.

The subtitled version is more formal than the dubbed one. The issue discussed is about God, His prophet and His servants. 


\section{Tenor:}

\section{Characters' Temporal, Geographical and Social Provenance:}

In dubbed version the accent of characters has been transferred. The kind and affable relationship between characters can also be seen.

\section{Characters' personal stance:}

The dubbed and subtitled copies also tried to keep the characteristics of Pi that keenly interested in God and His creatures. He is a bright, curious and assertive man.

The priest character conveyed. Therefore; there is no mismatch in this part.

\section{Social role relationship:}

In this part there is no mismatches between the original and the dubbed and subtitled versioned.

\section{Social role attitude:}

The conversational style is also the same as the original.

\section{Mode:}

The dubbed segment is fully spoken besides having the welcoming conversation. Using of broken and colloquial words is seen and the type of translation is Covert.

The subtitled one is fully written and the type of translation is Overt.

\section{Script4}

Father: You think that tiger is your friend.

He is an animal, not a playmate!

Pi: I just wanted to say 'Hello' to him.

Animals have souls. I've seen it in their eyes.

\section{Field:}

This excerpt presents a conversation between the father and 
his son at a cage of a tiger in their zoo. This part illustrates a quarrelsome language. They have an Indian accent.

In this segment, cases of unpleasant loud sound, unkind and harsh behavior can be seen.

\section{Tenor:}

\section{Characters' Temporal, Geographical and Social Provenance:}

They are the members of a family. The father and his son both have an Indian accent. Father is the owner of a zoo in India.

\section{Characters' personal stance:}

$\mathrm{Pi}$ is a spiritual person. He deeply believes in God and also has a remarkable intuition about His creatures.

Father is strict and bad-tempered. He always makes fun of his son. And also he does not believe in his son's words or act.

\section{Social role relationship:}

The two characters are the members of a family, father and son. Father's understanding of any subject specially the religious' belief was diverse and different from his son, $\mathrm{Pi}$.

\section{Social role attitude:}

The conversational style is mixed with unpleasant and unkind behavior can be seen between the two characters.

\section{Mode:}

This segment is fully spoken, simple and has a quarreling conversation.

\section{Dubbing4}

$$
\begin{aligned}
& \text { بإر:خيال كردياون ببر دوستته ؟ اون يه حيوونه نه يه همبازى. } \\
& \text { يایى: من فقط مى خو استم بهش سلام كنم تازه حيووناهم روح دارن من تو } \\
& \text { جشماشونديام }
\end{aligned}
$$

\section{Subtitling4}




$$
\begin{aligned}
& \text { بإر: فكر كردي اون ببر، دوستته؟اون يه حيوونه نه همبازى } \\
& \text { پایى: من فقط ميخو استم بهش سلام كنم حيوانات هم روح دارن } \\
& \text { توي جشمهاشون ديدم }
\end{aligned}
$$

\section{Field:}

The dubbed and subtitled copies show a conversation between father and his son at a cage of a tiger in their zoo.

Dubbed copy has also attempts to keep the Indian characteristics accent. This part illustrates a quarrel, unpleasant loud sound and unkind behavior. The subtitled copy is more general than the dubbed one.

\section{Tenor:}

\section{Characters' Temporal, Geographical and Social Provenance:}

In dubbed version the accent of father and his son has been transferred. Father is the owner of a zoo in India.

\section{Characters' personal stance:}

Both the dubbed and subtitled copies also tried to keep the characteristics of Pi who is spiritual and deeply believes in God who also has a remarkable intuition about His creatures.

Father's character was conveyed in the translations.

\section{Social role relationship:}

The two characters are father and son and their relationship also remains the same.

\section{Social role attitude:}

The conversational style also remained unchanged.

\section{Mode:}

The dubbed segment is fully spoken. Using of quarrelsome and colloquial word is seen and the type of translation is Covert; While,

\section{Translation Today}


the subtitled one is fully written and the type of translation is Overt.

\section{Script5}

FRENCH COOK: Vegetarian - the cow that produced this liver was vegetarian, the pigs

that went into these sausages were vegetarian.

FATHER: Very funny. But she doesn't eatliver.

\section{Field:}

This excerpt reveals a conversation between two strangers, a cook and father at a restaurant on a board of the ship. This part illustrates a quarrel language.

In this segment, cases of ridicule and harsh behavior can be seen.

\section{Tenor:}

\section{Characters' Temporal, Geographical and Social Provenance:}

Father is the owner of a zoo in India. He transfers his animals to another country by ship.

Cook is the chef in the ship by which Pi's family traveled.

\section{Characters' personal stance:}

Father is strict, serious and has an eye on his family specially his wife.

The cook is bad-tempered, narcissistic and has a rude language.

\section{Social role relationship:}

Father and the cook are both strangers and are not familiar with each other. They meet one another at the restaurant on the ship by which Pi's family traveled to Canada. 
The man, the cook, has a Canadian accent which is contemporary and low-class.

\section{Social role attitude:}

The conversational style combined with unpleasant and harsh behavior can be seen between the characters.

\section{Mode:}

This segment is fully spoken, quarreling and has an argumentative conversation.

\section{Dubbing5}

$$
\begin{aligned}
& \text { آثبِز فرانسوى: غذاى كياهى!!كَاوى كه اين جكر رو ازش كرفتن كياه خوار بوده } \\
& \text { الاغ هايى هم كه توى سوسيس استفاده شدن كياه خوار بودن. } \\
& \text { بِّر: خيلى بامزه بود.ولى كَتم همسرمن جكر نميخوره }
\end{aligned}
$$

\section{Subtitling5}

$$
\begin{aligned}
& \text { آشبِز فرانسوى: غذاى كَاهى!!گَاوى كه اين جكر رو تهيه كرده كياه خوار بوده } \\
& \text { خوك هايي هم كه نوى سوسيس بكار رفتن كياه خوار بودن. } \\
& \text { بإر: خيلى خنده دار بود. ولى همسر من جكر نميخوره }
\end{aligned}
$$

\section{Field:}

The dubbed and subtitled excerpts like the original script manifest a conversation between two strangers, a cook and the father at a restaurant on a board of the ship. A quarrel language, ridicule and harsh behavior can be seen.

\section{Tenor:}

\section{Characters' Temporal, Geographical and Social Provenance:}

This part remains unchanged in the translations and in dubbed version the accent of both characters has been transferred. 


\section{Characters' personal stance:}

The dubbed and subtitled versions like the original script have tried to show the characteristic of Father that is strict, serious and has an eye on his family specially his wife. The cook's character has also been transferred in both subtitled and dubbed versions who is bad-tempered, narcissistic and has a rude language.

\section{Social role relationship:}

This part has no difference with the original.

\section{Social role attitude:}

This part also remains unchanged.

\section{Mode:}

The dubbed segment is fully spoken besides having the quarreling and argumentative conversation, and the type of translation is Covert. In the dubbed version the word 'pigs' is translated incorrectly to الاغ ها'(donkeys) while, there exists an equivalent for it in Persian 'خوك هاغ 'خا' '; therefore, there is no need to change the symbol of the word.

The subtitled is fully written and the type of translation is Overt.

On one hand, as different films have different genres and different characters have different registers so we cannot compare the findings of this study with the findings of the previous ones. On the other hand as we do not have enough articles which applied house's model on AVT translation, again comparing and contrasting the results will not be possible. Furthermore, different films translated differently according to their genres; thus, we cannot say that all the subtitled films are overt and all the dubbed versions of the films are covert, just we can mention that the films which have the same genre as the film studied here may have overt subtitled and covert dubbed version.

From mismatches point of view the results of this article can be compared by the result of Bahrami and Ameri (2014), as an example 
they found out that in "Good Will Hunting" the dubbed version has some mismatches with its origin, but here we encountered the mismatches mostly in the field and mode in both subtitling and dubbing versions.

\section{Conclusion}

The analysis of English script and Persian subtitling and dubbing of "Life of $\mathrm{Pi}^{\text {" }}$ revealed the fact that most of mismatches occurred in field then in mode and no mismatch occurred in tenor. There was no noticeable difference between the generality and specificity in fields of dubbing and subtitling. Informality had the highest frequency in subtitling and formality had the highest frequency in dubbing. As also mentioned in the literature review, subtitling at all times throughout watching the movie reminded visually of the translated words to the viewers and signaling its foreign origin but in dubbing which was a covert translation the audience was not aware of listening to a translated text; so it was possible to use more formal expressions in dubbing than in subtitling in which the audience was aware of the translation and may have the source language knowledge to some extent; it was not possible to change the informality of the original to formality in translation. Mode does not always match between Persian subtitling and dubbing; the mismatches were related to the nature of these two methods, that subtitling was written and dubbing spoken.

As the answer to the second research question, we can notify that in the subtitled version the translator used overt translation and in the dubbed version, covert translation was applied.

As a conclusion, although all of these mismatches among the scripts, dubbing, and subtitling occurred along the examples, they did not have any effect on transferring the intended meaning of the original and all the equivalences were functional pragmatic to fulfill the expected meaning as it was House's expectation of a proper translation and mentioned in the literature review. 


\section{Appendices:}

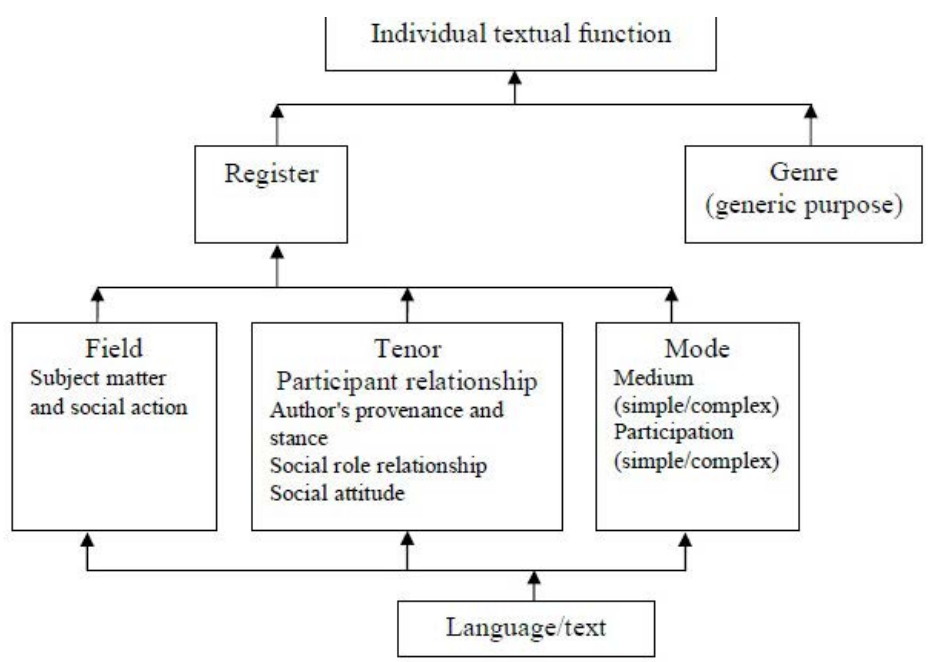

Figure 1. House's system for analyzing and comparing original and translated texts (House, 1997, p. 108; 2009, p. 35; 2013, p. 544) 


\section{Mismatches}

Table.

\begin{tabular}{|c|c|c|c|c|}
\hline & Mismatch & Field & Tenor & Mode \\
\hline 1. Subtitling & 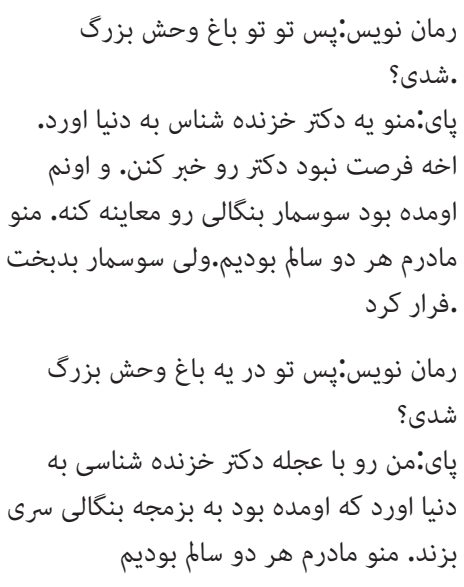 & 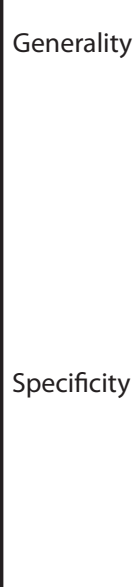 & & Spoken \\
\hline 2. Dubbing & 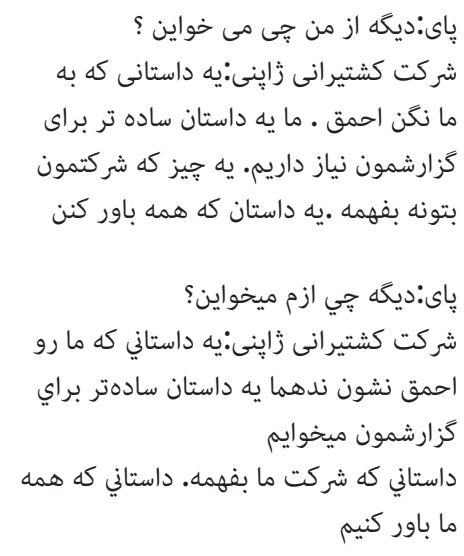 & 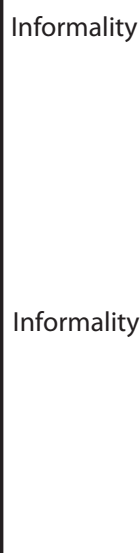 & & Spoken \\
\hline
\end{tabular}


Najmeh Bahrami Nazarabadi

\begin{tabular}{|c|c|c|c|}
\hline 3. Subtitling & 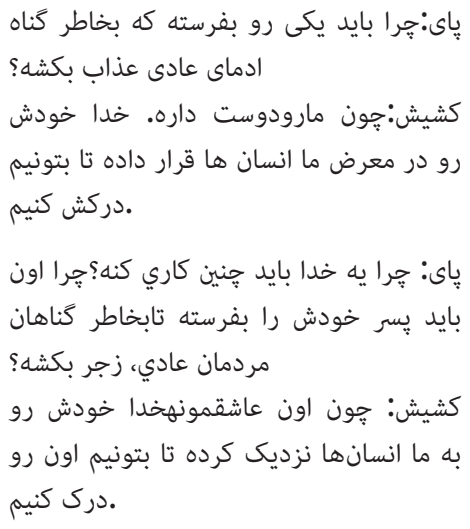 & 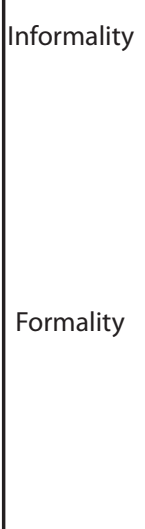 & Written \\
\hline 4. Dubbing & 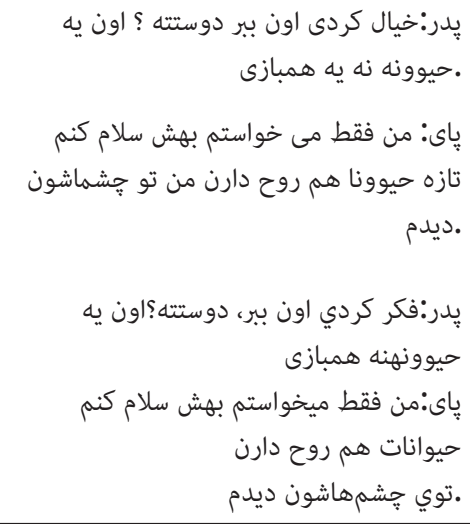 & Specificity & Spoken \\
\hline 5. Subtitling & 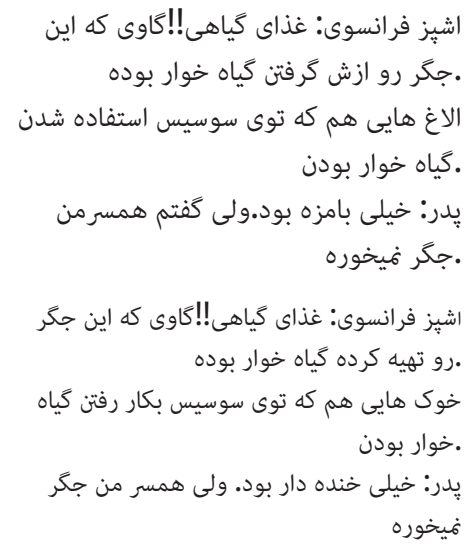 & Informality & Written \\
\hline
\end{tabular}




\section{REFERENCES}

- Ameri, S. \& Bahrami, N. (2014). Register Analysis in Dubbing: A Case Study.

Proceedings from: The First National Conference on Translation Studies, Kerman Institute of Higher Education

- Gottlieb, H. (2004). Language-political implications of subtitling In P.Orero (Ed.), Topics in audiovisual translation (pp.83-100).

- House, J. (2001). Translation Quality Assessment: Linguistic Description versus Social

evaluation. Meta, XLVI(2), 243-257

- House, J. (1997).Translation Quality Assessment: A Model Revisited. Tübingen: Narr

- House, J. (1981). A Model for Translation Quality Assessment (2nd Ed.).Germany: Gunter Narr Verlag Tübingen.

- Kapsaskis, D. (2008). New voices in translation studies. Special conference issue, With/out theory: The role of theory in translationstudies research

- Khedmatgozar, H. Eslami Rasekh, A. (2013). Functionalpragmatic model of translation assessment: A case study of two translations of Lessing's Ben in the world, International Journal of Research on English Language Teaching Studies, v 2(1) February 2013, pp: 8-16

- Luyken, G. (1991). Overcoming Language Barriers in Television: Dubbing and

Subtitling for the European Audience Düsseldorf: European Institute for the Media

- Munday, J. (2012). Introducing translation studies (3rd Ed.). USA: Routledge 
- O'Connell, E. (2007). Screen Translation. In P. Kuhiwczak \& K. Littau (Eds.), A companion to translation studies (pp.120-133). Toronto: Multilingual Matters Ltd.

- Pettit, Z. (2014). The audio-visual texts: subtitling and dubbing different genres. Meta: journal des traducteurs / Meta: Translators'journal, vol. 49, n 1, 2004, p. 25-38.

- Shakernia, S. (2014). Study of Houses Model of Translation Quality Assessment on the Short Story and Its Translated Text, Global Journal of Human Social Science Research. v14, No 3

- http://faculty.ksu.edu.sa/aljarf/Research\%20Library/ Translation\%20references/Meta2.pdf http://screenplayexplorer.com/wp-content/scripts/life-of-Pi. pdf

http://sub.subtitlepedia.com/download/ viewdownload/20/3605 http://s81.uploadboy.com:8080/d/ njvlzejdfx3pohyurgts645mg4gq6nl6gqqdqvuyzbq4nisf4xjc w4/life\%20of\%20Pi\%201.mkv 